Autor:

\title{
Delivar Tadeu de Mattos
}

Título:

\section{O consentimento do ofendido no direito penal}

Banca Examinadora:

Presidente: Dr. Luiz Alberto Machado

Dr. René Ariel Dotti

Dr. Miguel Reale Júnior

Defesa: $\quad 17$ de março de 1992.

\section{Resumo}

A dissertação aborda a moderna concepção do consentimento do ofendido que lhe dá o direito comparado cotejando-o com a legislação penal pátria. Analisa-o sob enfoque de perspectivas diferentes: a) quando se concede eficácia ao consentimento do titular do bem jurídico protegido como elemento do tipo de injusto do respectivo delito. Assim, por exemplo, o delito de violação de domicílio é construído com base na oposição do dono a quem ingresse ou permaneça na sua casa (artigo 150). O consentimento por ele dado torna impossível a configuração do próprio fato previsto como crime na lei penal; b) quando o consentimento aparece como elemento indispensável à configuração do próprio tipo objetivo como ocorre no aborto (artigo 126) e no rapto (artigo 220) consensuais. Nesta hipótese, a ausência de consentimento exclui o crime, por faltar ao tipo um de seus elementos essenciais; e c) o consentimento do ofendido como causa de exclusão de ilicitude. Examina-se, assim, a disponibilidade dos bens jurídicos e os seus limites: a ordem pública e os bons costumes. Conclui-se que o consentimento do ofendido é um instituto perfeitamente individualizado, no Direito Criminal, através do qual se dá a exclusão da ilicitude do fato com base na vontade do consenciente. 